\title{
Violence and related factors among high school students in semirural areas of Eskisehir
}

\author{
Burcu Isiktekin Atalay, ${ }^{1}$ Egemen Unal, ${ }^{1}$ Muhammed Fatih Onsuz, ${ }^{1}$ Burhanettin Isikli, ${ }^{1}$ Cinar Yenilmez, $^{2}$ \\ Selma Metintas ${ }^{1}$ \\ ${ }^{1}$ Department of Public Health, Osmangazi University, Faculty of Medicine, Eskisehir, Turkey \\ ${ }^{2}$ Department of Pyschiatry, Osmangazi University, Faculty of Medicine, Eskisehir, Turkey
}

\begin{abstract}
OBJECTIVE: The aim of the study was to determine the frequency of violence-related behaviors and related factors at school or school environment among high school students educated in the semirural areas of Eskisehir.

METHODS: This was a cross-sectional study. The sample comprised 1465 high school students. Data were collected using a questionnaire that included questions regarding sociodemographic characteristics and the 2013 survey questions of the "Youth Risk Behavior Surveillance System" of the Centers for Disease Control and Prevention.
\end{abstract}

RESULTS: It was found that $8.5 \%$ of students exhibited violent behaviors at school or school environment. According to multiple logistic regression analysis, sex, father's employment status, smoking, alcohol use, and feeling unsafe were effective independent variables on violence.

CONCLUSION: Students had a high rate of violence-related behaviors at school or school environment. Community-based public health interventions are required to solve this problem.

Keywords: Violence; risk factor; adolescent; semirural; high school student.

Cite this article as: Isiktekin Atalay B., Unal E., Onsuz M. F., Isikli B., Yenilmez C., Metintas S. Violence and related factors among high school students in semirural areas of Eskisehir. North Clin Istanb 2018;5(2):125-131.

$\mathrm{V}$ iolence is a critical public health problem that has been increasing. The World Health Organization (WHO) defines violence as the deliberate use of physical force or power, threatened or actual, against oneself, another person, or against a group or community, which either results in or has a high likelihood of resulting in injury, death, psychological harm, maldevelopment, or deprivation. Every year, more than 1 million people die because of violence and several nonfatal injuries occur as well [1]. Moreover, violence adversely influences the quality of life apart from contributing to disease, death, and disability [2]. Because violence affects the lives of millions in the long term, it is a risk factor for lifelong health and social problems [3].
Adolescents as a whole are among the groups that are the most vulnerable to violence. In addition, violence caused by adolescents is one of the most overt forms of violence prevailing in the society $[1,2]$. WHO defines the 10-19 age group, the period after childhood before adulthood, as adolescence. This period is a dynamic period wherein physical, psychological, and social maturity reach completion and adulthood-specific roles, responsibilities, and behaviors are acquired. This age group is generally considered healthy $[4,5]$. Conversely, adolescents are both perpetrators and victims of violence, which does not only influence them but also affects their families, friends, and societies [1]. Physical fights, bullying, and gun possession are crucial risk behaviors. In addition, us-

Received: July 25, 2017 Accepted: October 04, 2017 Online: April 11, 2018

Correspondence: Dr. Muhammed Fatih ONSUZ. Department of Public Health, Osmangazi University, Faculty of Medicine, Eskisehir, Turkey Phone: +90222 2392979 e-mail: fatihonsuz@yahoo.com

(c) Copyright 2018 by Istanbul Provincial Directorate of Health - Available online at www.northclinist.com 
ing lethal weapons, such as guns or knives, is common [1, 3]. Every day, approximately 565 people aged 10-29 years die because of violence [1]. According to the 2010 data of the Center for Disease Control and Prevention (CDC), homicide is the second cause for the death of people aged 15-24 years in the United States. In addition, $82.8 \%$ of the death of the people aged 10-24 years occurred with a gunshot [6]. The School Crime and Safety Indicators report stated that 33 deaths related to school violence occurred in the 2009-2010 among children aged 5-18 years [7]. According to a WHO study that was conducted in 133 countries, violence was observed among $26.0 \%$ of adolescents [3]. A study in Turkey found $44.0 \%$ of high school students to be exposed to verbal violence, $30.0 \%$ to physical violence, $18.0 \%$ to emotional violence, and $9.0 \%$ to sexual violence [8]. Adolescents who are involved in an act of violence during high school usually continue this behavior during their adulthood [1]. Thus, there is a need to study the dimensions of violent adolescent behavior to improve the health of adolescents and reduce problematic behaviors associated with health. Interventions conducted in this period may prevent dangers arising from violent behavior [3].

The aim of the study was to determine the frequency of violent behaviors among high school students in and around school in the semirural areas of Eskisehir and to indicate factors related to these behaviors.

\section{MATERIALS AND METHODS}

\section{Setting and participants}

This cross-sectional study was conducted in the 2014 academic year in high schools of four districts (Alpu, Mahmudiye, Beylikova, and Sivrihisar) forming the education and research area of the Eskisehir Osmangazi University School of Medicine. The frequency of students carrying weapons, such as guns, knives or sticks, which is a criterion for violent behavior, was used to determine the sample size. This frequency has been shown to range from $5.2 \%$ to $15.3 \%$ in Turkey [9-11]. Given $15 \%$ frequency, $3 \%$ margin of error, and $95 \%$ confidence intervals, the sample size for this study was calculated as at least 1225 . The sample comprised 1465 high school students who were present in the school during the study and whose verbal permissions were received.

\section{Measures}

A questionnaire was prepared comprising two sections by benefiting from the literature; the first section inves- tigated sociodemographic characteristics of students, and the second section comprised some questions from the 2013 questionnaire of CDC's Youth Risk Behavior Surveillance $[1,2,10,12-14]$. This questionnaire inquired about the risky behaviors that can lead to death and disability in adolescents and adults under six headings. Violence-related behaviors were captured by asking questions regarding weapon possession, the lack of a sense of security, armed threats, clothing or book theft, fights with injuries, and fights around school. Questions related to unwanted pregnancy, behaviors causing sexually transmitted diseases, and drug usage were removed from the questionnaire because of the social and cultural characteristics of the sample region.

The dependent variable of this study was determined using questions such as "how many days have you carried a gun with you in the last 30 days" and "how many times have you been involved in a fight in or around school in the last 12 months." The frequency of these behaviors was rated as "never," "at least once," or "more than once." Students who were involved in both these situations at least once were considered to be involved in a violent behavior. The family income of students in the study was evaluated as good, medium, and bad as per their own perception. Parents who were actively working on any job that delivered income were considered as "working." Necessary permissions were obtained from the district Directorate of Education and related school executives. Later, school visits were performed at designated appointment dates and hours and students were made to come together in their classes. After informing students about the subject and purpose of the study, their verbal consents were obtained. This study complied with the Declaration of Helsinki. The questionnaires were answered by students themselves under observation.

\section{Statistical analyses}

Data were evaluated using IBM SPSS (version 20.0) Statistics Package Program. For analyzing the differences between groups, univariate analysis was used, and odds ratio (OR) and 95\% confidence intervals (CI) were obtained. In addition, multiple logistic regression analysis was used to identify variables that influence violent behavior. A model was constructed with eleven independent variables (class, sex, family income, education of mother, job situation of father, smoking status, alcohol consumption status, sense of safety status in school, physical activity participation status, TV watching sta- 
TABLE 1. Distribution according to sociodemographic characteristics of the study group

\begin{tabular}{|c|c|c|}
\hline & $\begin{array}{c}\text { Sociodemographic } \\
\text { characteristics }\end{array}$ & $\begin{array}{c}n(\%) \\
n: 1465\end{array}$ \\
\hline \multirow[t]{2}{*}{ Class } & $9-10$ grade & $854(58.3)$ \\
\hline & $11-12$ grade & $611(41.7)$ \\
\hline \multirow[t]{2}{*}{ Gender } & Male & $759(51.8)$ \\
\hline & Female & $706(48.2)$ \\
\hline \multirow[t]{2}{*}{ Family type } & Nuclear family & $1282(87.5)$ \\
\hline & Extended family & $183(12.5)$ \\
\hline \multirow[t]{3}{*}{ Socioeconomic status } & Higher income & $357(24.4)$ \\
\hline & Middle income & $1022(69.8)$ \\
\hline & Lower income & $86(5.8)$ \\
\hline \multirow[t]{2}{*}{ Mother's education level } & $\begin{array}{c}\text { Primary school } \\
\text { and lower }\end{array}$ & $938(64.0)$ \\
\hline & $\begin{array}{l}\text { Middle school } \\
\text { and higher }\end{array}$ & $527(36.0)$ \\
\hline \multirow[t]{2}{*}{ Father's education level } & $\begin{array}{c}\text { Primary school } \\
\text { and lower }\end{array}$ & $633(43.2)$ \\
\hline & $\begin{array}{l}\text { Middle school } \\
\text { and higher }\end{array}$ & $832(56.8)$ \\
\hline \multirow[t]{2}{*}{ Mother's working status } & Employed & $263(18.0)$ \\
\hline & Unemployed & $1202(82.0)$ \\
\hline \multirow[t]{2}{*}{ Father's working status } & Employed & $1189(81.2)$ \\
\hline & Unemployed & $276(18.8)$ \\
\hline \multirow[t]{2}{*}{ Smoking } & No & $1201(82.0)$ \\
\hline & Yes & $264(18.0)$ \\
\hline \multirow[t]{2}{*}{ Alcohol consumption } & No & $1170(79.9)$ \\
\hline & Yes & $295(20.1)$ \\
\hline \multirow[t]{2}{*}{ Making physical activity status } & No & $659(45.0)$ \\
\hline & Yes & $806(55.0)$ \\
\hline \multirow[t]{2}{*}{ Watching TV status } & No & $351(24.0)$ \\
\hline & Yes & $1114(76.0)$ \\
\hline \multirow[t]{2}{*}{ Computer use status } & No & $516(35.2)$ \\
\hline & Yes & $949(64.8)$ \\
\hline
\end{tabular}

tus, and computer use status), which gave $\mathrm{p} \leq 0.01$ in one variable analysis. $\mathrm{P} \leq 0.05$ was considered statistically significant.

\section{RESULTS}

The average age of high school students was $16.03 \pm 1.19$ years, and $51.8 \%(n=759)$ were males, $87.5 \%(n=1282)$ grew up in a nuclear family, and $69.8 \%(\mathrm{n}=1022)$ were from middle income families. The distribution of students according to the socio demographic characteristics is given in Table 1 .
TABLE2. Distribution according to violence-related behaviors in the school and school environment of the study group

\begin{tabular}{lc}
$\begin{array}{l}\text { Violence-related } \\
\text { behaviors ( } \mathrm{n}: 1465)\end{array}$ & $\begin{array}{c}\text { To have at least } \\
\text { violent behav } \\
\mathrm{n}(\%)\end{array}$ \\
\hline Had a weapon $^{\mathrm{a}}$ & $183(12.5)$ \\
Lack of sense of security $^{\mathrm{a}}$ & $291(19.9)$ \\
Threatened of weapon $^{\mathrm{b}}$ & $149(10.2)$ \\
Clothes or books is stolen $^{\mathrm{b}}$ & $401(27.4)$ \\
Involved in an injury fight $^{\mathrm{b}}$ & $223(15.2)$ \\
Involved in a fight at $_{\text {school environment }}^{\mathrm{b}}$ & $515(35.2)$
\end{tabular}

aLast 30 days bLast 12 months.

Of all surveyed students, $12.5 \%(\mathrm{n}=183)$ reported that they carried a weapon at least once in the last 30 days, $10.2 \%(n=149)$ reported that they had been threatened with a weapon in and around school, 15.2\% $(n=223)$ reported that they were involved in fights that caused injuries or required treatment, and $35.2 \%(n=515)$ reported that they were involved in a fight in or around the school at least once in the last 12 months. The distribution of students according to violent behavior in schools is shown in Table 2 .

It was observed that $8.5 \%(n=125)$ of students had been involved in a violent behavior. According to the univariate logistic regression analysis, students with 11-12 grades [OR (\%95 GA), 1.94 (1.34-2.82)], males [10.11 (5.52-18.51)], students with lower family incomes [2.19 (1.10-4.37)], students whose mothers' education level was middle school or higher $[1.78(1.23-2.58)]$, students with unemployed fathers [2.20 (1.47-3.28)], students who smoked [6.96 (4.74-10.21)], students consuming alcohol [8.93 (6.04-13.22)], students feeling unsafe [3.04 (2.07-4.46)], students who were physically active $[1.89(1.28-2.81)]$, students who watched TV [1.96 (1.17-3.28)], and students who used computer [2.90 (1.79-4.69)] were involved in violent behavior in and around school.

According to the multiple logistic regression analysis, sex [4.66 (2.43-8.95)], employment status of father [2.27 (1.38-3.75)], smoking status [2.56 (1.61-4.07)], alcohol consumption status $[3.85(2.42-6.12)]$, and a sense of security status $[2.88(1.82-4.55)]$ were independent variables on violent behavior. The results of univariate and multivariate analyses of the factors influenc- 
TABLE 3. Results of univariate and multivariate analyses of factors influencing the behavior, including violence in school and school environment, of students who participated in the study

\begin{tabular}{|c|c|c|c|}
\hline & $\begin{array}{l}\text { Show behavior } \\
\text { including violence in } \\
\text { school and school } \\
\text { enviroment } \mathrm{n}(\%)\end{array}$ & $\begin{array}{l}\text { Univariate analysis } \\
\text { OR }(95 \% \mathrm{Cl})\end{array}$ & $\begin{array}{c}\text { Multivariate analysis } \\
\text { OR }(95 \% \mathrm{Cl})\end{array}$ \\
\hline \multicolumn{4}{|l|}{ Class } \\
\hline $9-10$ grade & $54(6.3)$ & 1 & \\
\hline $11-12$ grade & $71(11.6)$ & $1.94(1.34-2.82)$ & \\
\hline \multicolumn{4}{|l|}{ Gender } \\
\hline Female & $12(1.7)$ & 1 & 1 \\
\hline Male & $113(4.9)$ & $10.11(5.52-18.51)$ & $4.66(2.43-8.95)$ \\
\hline \multicolumn{4}{|l|}{ Socioeconomic status } \\
\hline Good & $29(8.1)$ & 1 & \\
\hline Moderate & $82(8.0)$ & $0.98(0.63-1.53)$ & \\
\hline Poor & $14(16.3)$ & $2.19(1.10-4.37)$ & \\
\hline \multicolumn{4}{|l|}{ Mother's education level } \\
\hline Primary school and lower & $64(6.8)$ & 1 & \\
\hline Middle school and higher & $61(11.6)$ & $1.78(1.23-2.58)$ & \\
\hline \multicolumn{4}{|l|}{ Father's working status } \\
\hline Employed & $85(7.1)$ & 1 & 1 \\
\hline Unemployed & $40(14.5)$ & $2.20(1.47-3.28)$ & $2.27(1.38-3.75)$ \\
\hline \multicolumn{4}{|l|}{ Smoking } \\
\hline No & $57(4.7)$ & 1 & 1 \\
\hline Yes & $68(25.8)$ & $6.96(4.74-10.21)$ & $2.56(1.61-4.07)$ \\
\hline \multicolumn{4}{|l|}{ Alcohol consumption } \\
\hline No & $46(3.9)$ & 1 & 1 \\
\hline Yes & $79(26.8)$ & $8.93(6.04-13.22)$ & $3.85(2.42-6.12)$ \\
\hline \multicolumn{4}{|l|}{ Feeling safe } \\
\hline Yes & $75(6.4)$ & 1 & 1 \\
\hline No & $50(17.2)$ & $3.04(2.07-4.46)$ & $2.88(1.82-4.55)$ \\
\hline \multicolumn{4}{|l|}{ Making physical activity status } \\
\hline No & $39(5.9)$ & 1 & \\
\hline Yes & $86(10.7)$ & $1.89(1.28-2.81)$ & \\
\hline \multicolumn{4}{|l|}{ Watching TV status } \\
\hline No & $18(5.1)$ & 1 & \\
\hline Yes & $107(9.6)$ & $1.96(1.17-3.28)$ & \\
\hline \multicolumn{4}{|l|}{ Computer use status } \\
\hline No & $21(4.1)$ & 1 & \\
\hline Yes & $104(11.0)$ & $2.90(1.79-4.69)$ & \\
\hline
\end{tabular}

ing students' violent behaviors in and around the school are given in Table 3.

\section{DISCUSSION}

Violence, which is an important cause of mortality and morbidity among adolescents, is a public health problem that is commonly seen worldwide. There is no single factor that can explain violence. These behaviors emerge as a result of an interaction between various factors [1, 3]. Our results indicate that sex, employment of father, smoking, alcohol consumption, and a sense of security in the school are the predictors of violent behavior. Other variables that were considered statistically significant in the univariate analysis but not in the multivariable analysis are not taken in the context of the discussion. 
Among the study students, $12.5 \%$ reported that they had possessed a gun in the last month and $10.2 \%$ reported that they had been threatened with a gun in the last month. Studies conducted in Turkey have indicated that $5.2 \%-15.3 \%$ adolescents carry a gun [9-11]. In addition, studies conducted in various countries have reported that $3.6 \%-17.3 \%$ adolescents carry a gun $[1,15,16]$. It is worrying that the result of this study is close to the upper limits of the ratio indicated in the results of previous studies, which suggests that adolescents have an easy access to weapons. However, this consequence may have emerged because our study was conducted in a semirural district with lower socioeconomic status. It has been reported that there is an easy access to weapons in schools that are located in districts with lower socioeconomic conditions [17]. Gun possession is one of the most important risky violent behavior for adolescents. Adolescents who consider that resorting to violence is necessary to protect themselves and their families carry weapons and threaten their environment. Such adolescents may be involved in more fights and, as a result, to feel more secure in fights, they continue to carry guns $[18,19]$.

In our study, $35.2 \%$ students reported that they were involved in a fight in or around school and $15.2 \%$ of them reported that they were involved in a fight where they could get injured. Studies have demonstrated that $24.5 \%-50.2 \%$ students are involved a fight in or around the school $[9-11,20,21]$, and studies conducted in the United States and Brazil have found this frequency to be between $6.5 \%$ and $33.0 \%[1,13,15,16,22]$. The results of our study and those of other studies conducted in our country are much higher than those of international studies. Adolescents do not prefer staying alone in the school and desire to be accepted by their peers. Adolescents consider it important to have a good position, popularity, leadership, and power among their school friends. From time to time, this need for possessing power and popularity may cause violent behaviors in adolescents [23]. Furthermore, during adolescence, which is an interim period between childhood and adulthood, acquiring a new identity and expressing the desire to make society accept this new identity or psychology that is developed by encountering a hard time, which they had not previously experienced, may have caused these results.

Our study found violent behavior to be more common among males, which is in line with the findings of previous studies $[1,9,10,13,21,24-28]$. Sex is considered an important predictor of violent behavior, and the tendency of male students to exhibit violent behavior may be explained by sex roles. The construct of sex refers to the roles, behaviors, activities, and qualifications that are created by the society for females and males [29]. Regarding sex roles, males with more traditional jurisdiction, which is encouraged by the society and benefited by males themselves, may be considered to be a factor supporting this result. The violent behavior of adolescent males may be related to tolerance shown to their behavior in the framework of social and cultural rules [20,30].

In line with the literature, students with unemployed fathers were more involved in violent behaviors in or around the school $[28,31]$. Because of the role that a society ascribes on the father, an unemployed father may create a restless environment in the house, which may cause the child to be engaged in violent behavior. In addition, an employed father may resort to violence to cope with problems in stressful environments, and, thus, children may learn violent behaviors from their fathers and tend to exhibit more violent behaviors.

Our study suggested that violent behaviors were more common among students who smoke. Smoking habit is an important public health problem in our country as well as worldwide. The age average of smokers has been reported to be declining day by day both in Turkey and worldwide [32]. Previous studies have suggested a relationship between violence and smoking [2, 21, 33, 34]. In contrast, Gofin et al. have reported no relationship between violence and smoking [35]. Smoking has been reported to cause several health problems in adolescents, and, thus, is an important factor for violent behaviors [2]. Smoking and violent behavior are crucial risky health behaviors [13]. Risky behaviors can trigger and be associated with each other.

In our study, alcohol consumption was shown to influence violent behaviors in students in and around the school. According to the WHO, 34.1\% of students aged 15-19 years consume alcohol worldwide. Alcohol is an important factor that can trigger violent behaviors and is an important cause of violence-related injuries $[1,12$, $34,36]$. Studies conducted in our country and those conducted worldwide have also suggested that students who consume alcohol are more engaged in violent behaviors $[12,21,33,37,38]$, which indicates that alcohol may be a cause for violent behaviors and that alcohol and violence may also trigger each other. People may be prone to apply violent behaviors in result of psychological effects caused by alcohol. In addition, conducting the study in rural areas may affect the results because providing alcohol as 
a weapon supply is easier in disadvantageous districts, and violent behaviors are more commonly observed in schools [17].

Approximately one-fifth of the students surveyed in this study stated that they did not go to school because they did not feel secure. In addition, students with a lack of a sense of security presented more violent behaviors. Studies conducted in Turkey have reported lower rates of students limiting their lives because they feel insecure than the rates reported in our study $[9-11,21,25]$. The desensitization of students about violence in the school or their different perceptions about the concept of feeling secure may reveal this consequence. Previous studies have revealed a relationship between feeling insecure and violence [22, 24]. It has been reported that students assuming school as insecure because of violence in the school cause their absence unless it is compulsory [39]. Violence in the school and a lack of a sense of security could be considered as interactive factors influencing each other. This cause an insecure environment in the school, and healthy education is not possible in such environments. Ensuring a safer school environment may make students and teachers feel physically, psychologically, and emotionally free and enable them to more comfortably express themselves.

There are some limitations of our study. First, instead of a direct observation of violent behaviors, we relied on behavioral characteristics defined by the students. Second, this was a cross-sectional study. Third, this study was conducted in the rural area of Eskisehir and, therefore, cannot be generalized to entire Turkey.

In conclusion, school violence is becoming an individual and social problem in Turkey as it is worldwide. In addition, our study determined that sex, father's employment status, smoking status, alcohol consumption status, and a lack of a sense of security affected violent behavior in and around school. Moreover, violent behavior was related to changeable risky behaviors. Society-based public health interventions toward changeable risky behaviors associated with violent behaviors will be crucial for preventing violence. Further, school management should make arrangements to provide security both in the school and in the school environment. Students should also be encouraged to share this with their families and teachers when exposed to violence. Effectively implemented school health services are required to improve these interventions. Interventions executed in this framework will assist adolescents to pursue their ed- ucation in a healthy and secure school environment and structure their future. The media can also play a role in this subject. Violent broadcasts must be effectively controlled, and educational programs on the subject should be made by media. Healthier adolescents far from violence will contribute toward constructing a healthy society in the future.

Conflict of Interest: No conflict of interest was declared by the authors.

Financial Disclosure: The authors declared that this study has received no financial support.

Authorship contributions: Concept - B.I.A., E.U., M.F.O., B.I., C..Y., S.M.; Design - B.I.A., E.U., M.F.O., B.I., Ç.Y., S.M.; Supervision - B.I.A., E.U., M.F.O., B.I., C..Y., S.M.; Materials - B.I.A., E.U., M.F.O., B.I., C..Y., S.M.; Data collection \&/or processing - B.I.A., E.U., M.F.O.; Analysis and/or interpretation - B.I.A., E.U., S.M.; Writing - B.I.A., E.U., M.F.O., B.I., Ç.Y., S.M.; Critical review - B.I.A., M.F.O., B.I., Ç.Y., S.M.

\section{REFERENCES}

1. Krug EG, Dahlberg LL, Mercy JA, Zwi AB, Lozano R. World report on violence and health. World Health Organization: Geneva; 2002.

2. Türkiye Büyük Millet Meclisi. Türkiyéde ortaöğretime devam eden öğrencilerde ve ceza ve infaz kurumlarında bulunan tutuklu ve hükümlü çocuklarda şiddet ve bunu etkileyen etkenlerin saptanması araştırma raporu. Ankara: Türkiye Büyük Millet Meclisi Arastırma Komisyonu; 2007.

3. World Health Organization. Global status report on violence prevention 2014. Available at: http://www.who.int/violence_injury_prevention/violence/status_report/2014/en/. Accessed Mar 29, 2018.

4. Turkish Statistical Institute. Statistics on Child 2014. Publication Number 4372. Ankara: Turkish Statistical Institute; 2015.

5. World Health Organization. Adolescent development. Available at: http://www.who.int/maternal_child_adolescent/topics/adolescence/ development/en/. Accessed Mar 29, 2018.

6. National Center for Injury Prevention and Control. Youth Violence Facts at a glance 2012. Available at: https://www.cdc.gov/violenceprevention/pdf/yv-datasheet-a.pdf. Accessed Mar 29, 2018.

7. National Center for Injury Prevention and Control. Youth violence prevention. Atlanta, GA: Centers for Disease Control and Prevention, 2015.

8. Haskan O, Yildirim I. Development of Violence Tendency Scale. Education and Science 2012;37:166-77.

9. Aras S, Gunay T, Ozan S, Orcin E. Risky behaviors among high school students in İzmir. Anadolu Psikiyatri Derg 2007;8:186-96.

10. Celbiş O, Karaoğlu L, Eğri M, Özdemir B. Violence among high school students in Malatya: a prevalence study. Turk J Med Sci 2012;42:343-50.

11. Eker HH, Tasdemir M, Ulger Z, Ozder A. Violence Related Behaviours among Adolescent Students and Factors Affecting Thereto. J Psychiatry 2015;18:239.

12. Anderson P, Baumberg Geiberg B. Alcohol in Europe: A public health perspective London: Institute of Alcohol Studies. Available at: https:// kar.kent.ac.uk/36384/. Accessed 29 Mar, 2018.

13. Kann L, Kinchen S, Shanklin SL, Flint KH, Kawkins J, Harris WA, et 
al; Centers for Disease Control and Prevention (CDC). Youth risk behavior surveillance--United States, 2013. MMWR Suppl 2014;63:1168.

14. World Health Organization. Health for the World's Adolescents: a second chance in the second decade. Available at: http://apps.who.int/ adolescent/second-decade/files/1612_MNCAH_HWA_Executive_ Summary.pdf. Accessed Mar 29, 2018.

15. Grunbaum JA, Kann L, Kinchen S, Ross J, Hawkins J, Lowry R, et al. Youth risk behavior surveillance-United States, 2003. MMWR Surveill Summ 2004;53:1-96. [CrossRef]

16. Substance Abuse and Mental Health Services Administration. Results from the 2005 National Survey on Drug Use and Health: National Findings. Available at: http://www.dpft.org/resources/NSDUHresults2005.pdf. Accessed Mar 29, 2018.

17. Limbos MA, Casteel C. Schools and neighborhoods: organizational and environmental factors associated with crime in secondary schools. J Sch Health 2008;78:539-44. [CrossRef]

18. Malek MK, Chang BH, Davis TC. Fighting and weapon-carrying among seventh-grade students in Massachusetts and Louisiana. J Adolesc Health 1998;23:94-102. [CrossRef]

19. Quinn GP, Bell-Ellison BA, Loomis W, Tucci M. Adolescent perceptions of violence: formative research findings from a social marketing campaign to reduce violence among middle school youth. Public Health 2007;121:357-66. [CrossRef]

20. Alikasifoglu M, Erginoz E, Ercan O, Uysal O, Kaymak DA, Iiter O. Violent behaviour among Turkish high school students and correlates of physical fighting. Eur J Public Health 2004;14:173-7. [CrossRef]

21. Alikasifoglu M, Erginoz E, Ercan O, Uysal O, Albayrak-Kaymak D. Bullying behaviours and psychosocial health: results from a cross-sectional survey among high school students in Istanbul, Turkey. Eur J Pediatr 2007;166:1253-60. [CrossRef]

22. Malta DC, do Prado RR, Caribe SS, da Silva MM, de Andreazzi MA, da Silva Júnior JB, et al. Factors associated with injuries in adolescents, from the National Adolescent School-based Health Survey (PeNSE 2012). Rev Bras Epidemiol 2014;17 Suppl 1:183-202. [CrossRef]

23. Cowie H. Bystanding or standing by: Gender issues in coping with bullying in English schools. Aggr Behav 2000;26:85-97. [CrossRef]

24. Earnest AA, Brady SS. Dating Violence Victimization Among High School Students in Minnesota: Associations With Family Violence, Unsafe Schools, and Resources for Support. J Interpers Violence 2016;31:383-406. [CrossRef]

25. Evren H, Tokuç B, Ekuklu G. Associations Between Violence Related Behaviors and Self Perceived Health Among Trakya University Students. Balkan Med J 2011;28:380-4.
26. He K, Kramer E, Houser RF, Chomitz VR, Hacker KA. Defining and understanding healthy lifestyles choices for adolescents. J Adolesc Health 2004;35:26-33. [CrossRef]

27. Ozcan S, Ergin A, Saatci E, Bozdemir N, Kurdak H, Akpinar E. The prevalence of risky behaviors related to violence in high school students in a southern city, Turkey. Coll Antropol 2008;32:1053-8.

28. Özgür G, Yörükoğlu G, Baysan Arabacı L. High School Student's Perception of Violence, Level of Tendency to Violence and Effective Factors. J Psy Nurs 2011;2:53-60.

29. World Health Organization. Gender, women and health - What do we mean by "sex" and "gender"? Available at: https;//www.legal-tools.org/ doc/a33dc3/pdf/. Accessed Mar 29, 2018.

30. Muula AS, Rudatsikira E, Siziya S. Correlates of weapon carrying among high school students in the United States. Ann Gen Psychiatry 2008;7:8. [CrossRef]

31. Saner H, Ellickson P. Concurrent risk factors for adolescent violence. J Adolesc Health 1996;19:94-103. [CrossRef]

32. Ozcebe H, Dogan BG, Inal E, Haznedaroglu D, Bertan M. Smoking Habits and the Related Sociodemographic Characteristics in University Students. Turk Thorac J 2014;15:42-8.33. Inand1 T, Ozer C, Akdemir A, Akoglu S, Babayigit C, Sangun O. Violence, psychological features, and substance use in high school students in Hatay: a crosssectional study. Balkan Med J 2009; 26: 189-196.

33. İnandı T, Özer C, Akdemir A, Akoğlu S, Babayiğit C, Turhan E, et al. Violence, Psychological Features, and Substance Use in High School Students in Hatay: a Cross-sectional Study. Trakya Univ Tip Fak Derg 2009;26:189-96.

34. Turhan E, İnandı T, Özer C, Akoğlu S. nce use, violence among university students and their some psychological characteristics. Turk J Public Health 2011;9:33-44. [CrossRef]

35. Gofin R, Palti H, Gordon L. Bullying in Jerusalem schools: victims and perpetrators. Public Health 2002;116:173-8. [CrossRef]

36. World Health Organization. Global status report on alcohol and health 2014. Available at: http://www.who.int/substance_abuse/publications/global_alcohol_report/en/.Accessed Mar 29, 2018.

37. Resnick MD, Ireland M, Borowsky I. Youth violence perpetration: what protects? What predicts? Findings from the National Longitudinal Study of Adolescent Health. J Adolesc Health 2004;35:424.e1-10.

38. Shepherd JP, Sutherland I, Newcombe RG. Relations between alcohol, violence and victimization in adolescence. J Adolesc 2006;29:539-53.

39. Bossarte RM, Swahn MH, Breiding M. Racial, ethnic, and sex differences in the associations between violence and self-reported health among US high school students. J Sch Health 2009;79:74-81. [CrossRef] 